\title{
Chemical composition and antioxidant, cytotoxic, and insecticidal potential of Valeriana alliariifolia in Turkey
}

\author{
Burcu Sen-Utsukarci ${ }^{1}$, Turgut Taskin ${ }^{2}$, Fatih Goger ${ }^{3}$, Nurhayat Tabanca ${ }^{4}$, Alden S. Estep ${ }^{5,6}$, \\ Sonja M. Kessler ${ }^{7}$, Ozlem Akbal-Dagistan ${ }^{8}$, Hilal Bardakci ${ }^{9}$, Mine Kurkcuoglu ${ }^{3}$ James Becnel ${ }^{6}$, \\ Alexandra Kiemer ${ }^{7}$, and Afife Mat ${ }^{1}$ \\ ${ }^{1}$ Istanbul University, Faculty of Pharmacy, Department of Pharmacognosy, Istanbul, Turkey \\ ${ }^{2}$ Marmara University, Faculty of Pharmacy, Department of Pharmacognosy, Istanbul, Turkey \\ ${ }^{3}$ Anadolu University, Faculty of Pharmacy, Department of Pharmacognosy, Eskişehir, Turkey \\ ${ }^{4}$ USDA-ARS, Subtropical Horticulture Research Station, Miami, FL, USA \\ ${ }^{5}$ Navy Entomology Center of Excellence, CMAVE Detachment, Gainesville, FL, USA \\ ${ }^{6}$ USDA-ARS, Center for Medical, Agricultural, and Veterinary Entomology, Gainesville, FL, USA \\ ${ }^{7}$ Saarland University, Department of Pharmacy, Pharmaceutical Biology, Saarbrucken, Germany \\ ${ }^{8}$ Istanbul University, Faculty of Pharmacy, Department of Pharmaceutical Technology, Istanbul, Turkey \\ ${ }^{9}$ Acibadem Mehmet Ali Aydinlar University, Faculty of Pharmacy, Department of Pharmacognosy, Istanbul, Turkey
}

[Received in March 2019; Similarity Check in March 2019; Accepted in September 2019]

Valeriana is a common plant species used for various healing purposes in folk medicine since antiquity. This study investigates the phytochemical profile, antioxidant, cytotoxic, and insecticidal activity of Valeriana alliariifolia Adams, a species that has traditionally been used in Turkey. For the analyses we prepared four root extracts of $V$. alliariifolia Adams using hexane (HM1), chloroform (CM1), ethanol (EM1), and water (WM1) for maceration. Additionally, two extracts were also prepared from its roots by maceration separately with ethanol (EM2) and water (WM2). One sample was prepared as a water infusion (WI), according to the procedure used in Turkish traditional medicine. The 2,2-Diphenyl1-picrylhydrazyl (DPPH) scavenging and 2,2'-azino-bis(3-ethylbenzothiazoline-6-sulphonic acid (ABTS) radical cation scavenging activity tests showed that ethanol extracts had the strongest antioxidant activity: EM1 (IC ${ }_{50}-$ DPPH: $17.694 \mu \mathrm{g} /$ $\mathrm{mL}$; ABTS: $23.8 \mu \mathrm{g} / \mathrm{mL}$ ) and EM2 (IC ${ }_{50}$ DPPH: $20 \mu \mathrm{g} / \mathrm{mL}$; ABTS: $21.5 \mu \mathrm{g} / \mathrm{mL}$ ). The hexane extract, HM1, was the most cytotoxic ( $\mathrm{IC}_{50}<10 \mu \mathrm{g} / \mathrm{mL}$ against HepG2 and HUVEC) and EM2 strongly cytotoxic $\left(\mathrm{IC}_{50}<10 \mu \mathrm{g} / \mathrm{mL}\right.$ against HepG2 and $\mathrm{IC}_{50}: 11.96 \mu \mathrm{g} / \mathrm{mL}$ against HUVEC). The extracts with demonstrated cytotoxic activities were further examined to check their insecticidal activity against adult female mosquito Aedes aegypti and first instar Ae. aegypti larvae. HM1 was the most effective $(90 \pm 10 \%$ ), which was consistent with its cytotoxic activity. Because of the high antioxidant, cytotoxic, and insecticidal activities, we ran phytochemical analyses of the HM1, EM1, and EM2 extracts with GC-MS (for HM1) and LC-MS/MS (for EM1 and EM2). We also analysed the composition of the essential oil obtained from $V$. alliariifolia roots by micro-distillation in order to compare its content with HM1, which contains volatile compounds. Phytochemical analyses revealed that the major compound in HM1 was isovaleric acid (16\%) and in the essential oil 1,8-cineole (2.9\%). EM1 and EM2 contained 5- $O$-caffeoylquinic acid (chlorogenic acid), verbascoside (acteoside), and 3,5-dicaffeoylquinic acid as major components. In the light of our findings and available literature, we can conclude that $V$. alliariifolia has a good bioactive potential that could be used for different purposes, including the development of new agents for the treatment of various diseases. The difference in the content between the essential oil and HM1 was remarkable. It suggests that the variability observed in the activity of the samples was a result of composition and that, therefore, the aim of treatment should dictate which type of preparation is to be selected. An added value of our study is that it determined verbascoside and methylquercetin rutinoside for the first time in the Valeriana extracts.

KEY WORDS: antioxidant activity; cytotoxicity, GC-MS; insecticidal activity; LC-MS/MS

The genus Valeriana (Caprifoliaceae) is represented by more than 350 species worldwide. In Turkey, there are about 17 species, of which four are endemic (1-5). In Turkey Valeriana officinalis L. is traditionally used for treating hysteria, neurasthenia, nervous insomnia, and palpitations. Its infusions are preferred for the treatment of wounds (6).

Corresponding author: Burcu Sen-Utsukarci, Department of Pharmacognosy, Faculty of Pharmacy, Istanbul University, 34116, Beyazit Istanbul, Turkey. E-mail address: burcusn@gmail.com
Although the main components of valerian - namely sesquiterpenes, iridoids, flavonoids, alkaloids, lignans, triterpenes, and monoterpenes - are known, its chemical composition varies with season $(7,8)$. Many of iridoids have been studied for their antispasmodic, sedative, antimycobacterial, antiviral, cytotoxic, and anxiolytic effects. Valepotriates take an important place among the iridoid compounds. They are cytotoxic and inhibit DNA synthesis. Additionally, 8-hydroxypinoresinol and 
prinsepiol displayed powerful antioxidant activity in Trolox equivalent antioxidant activity (TEAC) and chemiluminescence $(\mathrm{CL})$ tests $(8,9)$.

$\mathrm{Xu}$ et al. (10) found that an iridoid-rich fraction from $V$. jatamansi Jones was extremely safe in the usual clinical dose, and had no single-dose toxicity. Its $\mathrm{LD}_{50}$ in mice was over $2000 \mathrm{mg} / \mathrm{kg}$, while the no-observed-adverse-effect level (NOAEL) for rats was $1200 \mathrm{mg} / \mathrm{kg} /$ day (10).

In spite of the evidence of low general toxicity, some studies (11-15) investigated the cytotoxic activities of extracts and isolated compounds, such as iridoids and sesquiterpenoids from the Valeriana species in various cell lines.

Data on the insecticidal activity of the Valeriana species are scarce. Dua et al. (16) studied the insecticidal effects of $V$. jatamansi extracts and essential oil. Median lethal concentration $\left(\mathrm{LC}_{50}\right)$ of the essential oil against the larvae of five mosquito species was in the range of 42.8 $80.6 \mathrm{mg} / \mathrm{L}$, while the $\mathrm{LC}_{50}$ in adult mosquitos ranged between 0.08 and $0.17 \mathrm{mg} / \mathrm{cm}^{2}$.

Tan et al. (17) found that $V$. jatamansi roots contained two neuroprotective compounds, isopatrinioside and vibutinal. Bardakçı et al. (18) reported that four compounds from $V$. alliariifolia Adams (valtrate, isovaleroxyvaltrate hydrin, acetoxyvaltrate hydrin, and isovaleroxyhydroxydihydrovaltrate) had a strong sedative effect on animals. They associated these neurotropic effects with higher levels of GABA and lower energy metabolism in the brain.

In traditional medicine in East Anatolia (Turkey), $\mathrm{V}$. alliariifolia root infusions are used as sedatives and antispasmodics (19). In the Usak region of Turkey $V$. officinalis is preferred for its analgesic and sedative effects (20), while on the west Mediterranean coast of Turkey they are used to treat neural conditions and as tranquilisers (21).

Some earlier studies investigated the contents of various Valeriana essential oils (20-26). One study with capillary gas chromatography (GC) and GC/mass spectrometry (MS) in the essential oil hydrodistilled from the subterranean parts of $V$. alliariifolia reported 68 components that accounted for $87.6 \%$ of the total oil. The major components were isovaleric acid $(28.6 \%), \delta$-guaiane $(7.2 \%)$, $\alpha$-humulene (4.7\%), hexadecanoic acid (4.3\%), valeric acid (3.7\%), and humulene epoxide-II (3.6 \%) (18).

In another study from Iran (4), the major volatile components of $V$. alliariifolia essential oil were transcaryophyllene (38.96\%), $\beta$-pinene $(12.06 \%), \alpha$-pinene (9.94\%), $\alpha$-terpinene $(9.49 \%)$, isoterpinolene $(7.15 \%)$, and 1,8-cineole $(6.76 \%)$.

Some Turkish studies have also assessed the biological activities of the Valeriana species. Ozdemir et al. (27) reported inhibitory effects of a $V$. officinalis extract on acetylcholinesterase (AChE) activity in human erythrocytes and serum in vitro. Karadeniz et al. (28) studied the antioxidant activity of $V$. dioscoridis SM. However, due to a small number of the Valeriana species in Turkey, the evidence gathered in these studies is limited.

The aim of our study was therefore to complement current knowledge about the Valeriana species with new findings of cytotoxic, antioxidant, and insecticidal activity tests and of phytochemical analyses of active extracts and essential oil from $V$. alliariifolia roots collected in a northeast region of Turkey.

\section{METHODS}

\section{Plant material}

The roots of $V$. alliariifolia Adams were collected from the Trabzon-Hamsiköy region in July 2012. The voucher specimen has been deposited with the Herbarium of the Faculty of Pharmacy, University of Istanbul (ISTE 98089).

\section{Preparation of extracts}

Dried and powdered roots (15 g) were successively macerated with 150mL hexane (HM1), $150 \mathrm{~mL}$ chloroform (CM1), $150 \mathrm{~mL}$ ethanol (EM1), and $150 \mathrm{~mL}$ water (WM1) for $24 \mathrm{~h}$ with occasional stirring. Another portion of root (7.5 g) was separately macerated with either $150 \mathrm{~mL}$ ethanol (EM2) or $150 \mathrm{~mL}$ water (WM2) for $24 \mathrm{~h}$ with occasional stirring. An infusion was also prepared from another portion of roots with boiled water (WI; $150 \mathrm{~mL}$ ) according to the traditional procedure. Organic extracts were evaporated to dryness in vacuo, and aqueous extracts lyophilised (Labconco, Kansas City, MO, USA). All extracts were stored at $\pm 4^{\circ} \mathrm{C}$ until further use.

\section{Antioxidant activity testing}

To determine antioxidant activity we used 2,2-diphenyl1-picrylhydrazyl (DPPH'), Folin-Ciocalteu's phenol reagent $2 \mathrm{~N}$, gallic acid, and ascorbic acid, all of analytical grade and obtained from Sigma Chemical Co. (St. Louis, MO, USA).

DPPH radical scavenging activity of the extracts was measured with the method proposed by Fu et al. (29). DPPH solution $(0.1 \mathrm{mmol} / \mathrm{L}$ in methanol, $3.9 \mathrm{~mL})$ was added to extracts $(0.1 \mathrm{~mL})$ prepared in dimethylsulphoxide (DMSO) at different concentrations $(5-0.5 \mathrm{mg} / \mathrm{mL})$. The mixture was then left at room temperature for $30 \mathrm{~min}$. The absorbance of the mixture was measured against reference using a spectrophotometer (UV-1800, Shimadzu, Kyoto, Japan) at $517 \mathrm{~nm}$.

2,2'-azino-bis(3-ethylbenzothiazoline-6-sulphonic acid $\left(\mathrm{ABTS}^{\cdot+}\right)$ radical scavenging activity was determined according to the method developed by Re et al. (30). Forty millilitres of extracts $(5-0.5 \mathrm{mg} / \mathrm{mL}$, in DMSO) prepared from plant material were mixed with $3960 \mu \mathrm{L}$ of the $\mathrm{ABTS}^{\cdot+}$ working solution. The absorbance of the mixture was measured against reference at $734 \mathrm{~nm}$ for $6 \mathrm{~min}$. The results were expressed as $\mathrm{IC}_{50}(\mu \mathrm{g} / \mathrm{mL})$. 
Total phenolic content of plant extracts was determined with the Folin-Ciocalteu reagent (FCR) method (31) Briefly, $0.1 \mathrm{~mL}$ of the extract $(5-0.5 \mathrm{mg} / \mathrm{mL}$, in DMSO) was put in a plate and $4.5 \mathrm{~mL}$ of water was added. Then, $0.1 \mathrm{~mL}$ of FCR (diluted with distilled water to the ratio $1: 3$ ) and $0.3 \mathrm{~mL}$ of $2 \%$ sodium carbonate solution were added to the mixture. The mixture was left at room temperature for $2 \mathrm{~h}$, and then absorbance was measured against the reference at $760 \mathrm{~nm}$ (UV-1800, Shimadzu, Kyoto, Japan). Total phenolic content was expressed as $\mu \mathrm{g}$ of gallic acid equivalents per mg of the extract.

\section{Cytotoxicity testing}

Cytotoxicity was tested with the 3-(4,5-dimethylthiazol2-yl)-2,5-diphenyltetrazolium bromide (MTT) colorimetric method as described earlier (32) in human liver carcinoma (HepG2) and primary human umbilical vein endothelial (HUVEC) cells.

HepG2 cells (HB-8065, controlled by DSMZ-German Collection of Microorganisms and Cell Cultures $\mathrm{GmbH}$, Germany, DSMZ ACC180) were maintained in RPMI-1640 with glutamine supplemented with $10 \%$ foetal calf serum (FCS), and a penicillin-streptomycin mixture. HUVEC cells were isolated from umbilical cords (obtained with the consent of donors and permission by the local ethics committee) by digestion with $0.01 \%$ collagenase A solution (Roche, Basel, Switzerland) and grown in Endothelial Cell Growth Medium with supplement mix (Promocell, Heidelberg, Germany; C-39215) containing $10 \%$ FCS, penicillin $(100 \mathrm{U} / \mathrm{mL})$ - streptomycin $(100 \mathrm{mg} / \mathrm{mL})$ mixture, and kanamycine $(50 \mathrm{mg} / \mathrm{mL})$. HepG2 cells were seeded into 96 -well plates at a density of $10^{4}$ cells per well and HUVEC cells at a density of $2 \times 10^{4}$ cells per well, and incubated to allow for cell attachment at $37{ }^{\circ} \mathrm{C}$ and $5 \%$ $\mathrm{CO}_{2}$ for $24 \mathrm{~h}$. After that, the cells were treated with $100 \mu \mathrm{L}$ serial concentrations of all extracts.

All test samples were dissolved in DMSO at the concentration of $20 \mathrm{mg} / \mathrm{mL}$. Stock solutions were diluted in the medium to obtain the final concentrations of 10 $200 \mu \mathrm{g} / \mathrm{mL}$. Negative control cells were grown in the medium only, while solvent control cells were grown with the addition of DMSO. Cell viability control showed that DMSO concentrations of up to $0.75 \%$ were not toxic. For each extract, all concentrations were tested in duplicate or triplicate. After $24 \mathrm{~h}$, the cells in each well were quantified with the MTT test (33-36).

For the MTT test, $150 \mu \mathrm{L}$ of MTT solution $(0.5 \mathrm{mg} / \mathrm{mL}$ in medium) was added to each well after aspiration of the medium, and incubated at $37^{\circ} \mathrm{C}$ for $3 \mathrm{~h}$. Formed formazan crystals were solved in $80 \mu \mathrm{L}$ of DMSO, and absorbance was measured at $550 \mathrm{~nm}$. The percentage of cell viability was calculated with respect to solvent control as follows:

$$
\% \text { Cell viability }=\mathrm{Abs}{ }_{\text {compounds }} / \mathrm{Abs}_{\text {solvent control }} \times 100
$$

\section{Insecticidal activity testing}

The mosquito colony of Aedes aegypti L. was obtained from the USDA/CMAVE insectary (Gainesville, FL, USA). Rearing procedures have been described elsewhere (37).

Larvicidal activity was tested as described by Pridgeon et al. (38) with minor modifications aimed to reduce the amount of test samples in 96-well plates (39). The hexane extract, HM1, was diluted with DMSO to the concentration of $100 \mu \mathrm{g} / \mu \mathrm{L}$. Larval mortality was determined at four concentrations $(1.0,0.5,0.25$, and $0.1 \mu \mathrm{g} / \mu \mathrm{L})$ in a final volume of $200 \mathrm{~mL}$ of larval rearing media. Each test included a positive control of the pesticide permethrin and a negative control of ethanol or DMSO. Tests were repeated at least three times on separate days using different hatches of eggs.

The toxicity of HM1 extract was also tested in 246 adult Ae. aegypti mosquitos using cohorts of three to six-day post-emergence females as described elsewhere (38). The mosquitoes were cold-anaesthetised on ice, and groups of 10 females distributed into separate plastic cups. The HA1K extract was diluted to a $10 \%$ solution with DMSO, which was subsequently serially diluted in acetone to the 1:10 ratio. Sample solution $(0.5 \mu \mathrm{L})$ was applied to the dorsal thorax of at least 20 female mosquitos per dose using a repeater pipettor (Hamilton PB600, Hamilton Company, Reno, NV, USA) with a $25-\mu \mathrm{L}$ blunt tip glass syringe (Hamilton 7100 series). A permethrin mixture of $46.1 \%$ cis- and 53.2 trans-isomers (Chemservice, West Chester, PA, USA) was used as positive control and acetone as negative control. After treatment, the mosquitoes were kept in plastic cups at $26-27^{\circ} \mathrm{C}$ and $80 \%$ humidity and received $10 \%$ sucrose in water for $24 \mathrm{~h}$ prior to recording mortality.

\section{Headspace solid-phase microextraction (HS-SPME) of HMI}

Volatiles were trapped by solid-phase microextraction (SPME) fibre coated with polydimethylsiloxane/ divinylbenzene-PDMS/DVB (Blue-65 $\mu \mathrm{m}$ ) (supplied by Supelco Inc., Bellefonte, PA, USA) with a sampling time of $30 \mathrm{~min}$ at $50^{\circ} \mathrm{C}$ (the extract was heated for $15 \mathrm{~min}$ before sampling). Thermal desorption was performed at $250{ }^{\circ} \mathrm{C}$ for $15 \mathrm{~min}$. The fibre was directly desorbed in GC-MS.

\section{Extract GC-MS analysis}

For GC-MS analysis we used an Agilent 5975 GC-MSD system (Agilent Technologies Inc., Santa Clara, CA, USA) and an INNOWax FSC column (polyethylene glycol, PEG; Agilent, Walt \& Jennings Scientific, Wilmington, DE, USA) (60 $\mathrm{m} \times 0.25 \mathrm{~mm}, 0.25 \mu \mathrm{m}$ film thickness) with helium as carrier gas $(0.8 \mathrm{~mL} / \mathrm{min})$. GC oven temperature was kept at $60{ }^{\circ} \mathrm{C}$ for $10 \mathrm{~min}$ and raised to $220^{\circ} \mathrm{C}$ at a rate of $4{ }^{\circ} \mathrm{C} /$ min, then kept constant at $220^{\circ} \mathrm{C}$ for $10 \mathrm{~min}$, and raised to $240{ }^{\circ} \mathrm{C}$ at a rate of $1{ }^{\circ} \mathrm{C} / \mathrm{min}$ in splitless mode. The injector temperature was $250{ }^{\circ} \mathrm{C}$. MS was taken at $70 \mathrm{eV}$. Mass 
range was from $\mathrm{m} / \mathrm{z} 35$ to 450 . The injection was repeated three times.

\section{Microdistillation of the roots}

Dried and crushed roots were placed in a sample vial together with $10 \mathrm{~mL}$ of water. $\mathrm{NaCl}(2.5 \mathrm{~g})$ and water $(0.5 \mathrm{~mL})$ were placed in the collecting vial. $\mathrm{n}$-Hexane $(300 \mu \mathrm{L})$ was added to the collecting vial to trap volatile components. Sample vials were heated to $108^{\circ} \mathrm{C}$ at a rate of $20^{\circ} \mathrm{C} / \mathrm{min}$, kept at $108^{\circ} \mathrm{C}$ for $90 \mathrm{~min}$, heated to $112^{\circ} \mathrm{C}$ at a rate of $20^{\circ} \mathrm{C} / \mathrm{min}$, and kept at this temperature for 30 min. Finally, the samples were subjected to a post-run for 6 min under the same conditions. Collecting vials were cooled to $-1{ }^{\circ} \mathrm{C}$ during distillation. Once the distillation was completed, the organic layer in the collection vial was injected $(1 \mu \mathrm{L})$ into a gas chromatograph with a flame ionisation detector (GC-FID) and GC-MS.

\section{Essential oil analysis}

The oils were analysed with GC-FID and GC/MS techniques simultaneously. The GC-FID analysis was carried out with a capillary Agilent $6890 \mathrm{~N}$ GC system. FID temperature was set at $300{ }^{\circ} \mathrm{C}$ in order to obtain the same elution order with the GC/MS. Injection was simultaneous using the same HP-INNOWax FSC column $(60 \mathrm{~m} \times 0.25$ $\mathrm{mm}, 0.25-\mu \mathrm{m}$ film thickness; Agilent, Walt \& Jennings) and appropriate operational conditions.

The components of essential oils were identified by comparing their mass spectra with those in the Baser Library of Essential Oil Constituents obtained from chromatographic runs of pure compounds performed with the same equipment and under the same conditions, Adams Library (40), MassFinder Library (41), and Wiley GC/MS Library (42) and confirmed by comparing their retention indices. The relative percentages of the separated compounds were calculated from FID chromatograms.

\section{Determination of phenolic compounds in EM1 and EM2} extracts

For LC-MS/MS analysis, we used the method described by Goger et al. (43) with some modifications. The experiments were performed with a Shimadzu 20A highperformance liquid chromatography (HPLC) system coupled to an Applied Biosystems 3200 Q-Trap LC-MS/ MS instrument (Thermo Fisher Scientific, Waltham, MA, USA) equipped with an electrospray ionisation (ESI) ion source in negative ionisation mode. Separations were done on a $\mathrm{C} 18$ reverse-phase (ODS $150 \times 4,6 \mathrm{~mm}$, i.d., $3 \mu \mathrm{m}$ particle size) analytical column operating at $40^{\circ} \mathrm{C}$ at a flow rate of $0.5 \mathrm{~mL} / \mathrm{min}$. HPLC elution was carried out using a binary gradient of solvent mixtures of methanol, water, and formic acid (10/89/1 v/v/v, respectively for solvent $\mathrm{A}$ and $89 / 10 / 1 \mathrm{v} / \mathrm{v} / \mathrm{v}$, respectively for solvent B). The composition of solvent B was increased from $10 \%$ to $100 \%$ in $40 \mathrm{~min}$.

\section{RESULTS AND DISCUSSION}

The results of the antioxidant tests (Table 1) show that EM1 and EM2 extracts had the highest antioxidant activity ( $\mathrm{IC}_{50} 17.69 \pm 0.34 \mu \mathrm{g} / \mathrm{mL}$ and $20.0 \pm 1.0 \mu \mathrm{g} / \mathrm{mL}$, respectively). EM1 and EM2 also exhibited the highest total phenolic content (TPC) $[113.8 \pm 1.2 \mu \mathrm{g}$ and $116.7 \pm 1.1 \mu \mathrm{g}$ of gallic acid equivalents (GAE) per mg of extract, respectively]. Antioxidant activities correlated with TPC. EM1 activity higher than that of EM2 (by DPPH) demonstrates that polar compounds have a role in antioxidant activity. Like polar extracts, ethanol extracts also showed higher activity than other extracts.

While the DPPH test showed higher EM1 than that of EM2, ABTS test showed higher EM2 activity and higher TPC. These findings suggest that compounds with antioxidant activity in this Valeriana species have high or moderate polarity.

HM1, CM1, and EM2 extracts exhibited cytotoxic activity on the HepG2 cell line (Table 2). HM1 and EM2

Table 1 DPPH and ABTS scavenging activities and total phenolic content of $V$. alliariifolia extracts

\begin{tabular}{lccc}
\hline Extracts and reference compounds & $\mathbf{D P P H}\left(\mathbf{I C}_{\mathbf{5 0}}-\boldsymbol{\mu \mathbf { g }} / \mathbf{m L}\right)$ & $\mathbf{A B T S}\left(\mathbf{I C}_{\mathbf{5 0}}-\boldsymbol{\mu g} \mathbf{m L}\right)$ & $\begin{array}{c}\text { Total phenolic content } \\
(\boldsymbol{\mu g} \text { of GAE per } \mathbf{~ m g ~ o f ~} \\
\text { extract) }\end{array}$ \\
\hline HM1 & $1397.3 \pm 2.3$ & $999.46 \pm 2.7$ & $35.47 \pm 1.2$ \\
\hline CM1 & $358.4 \pm 2.5$ & $188.92 \pm 1.1$ & $26.3 \pm 1.07$ \\
\hline EM1 & $17.69 \pm 0.34$ & $23.8 \pm 0.6$ & $113.8 \pm 1.2$ \\
\hline WM1 & $45.13 \pm 0.5$ & $46.4 \pm 0.5$ & $62.5 \pm 0.8$ \\
\hline EM2 & $20.0 \pm 1.0$ & $21.5 \pm 0.1$ & $116.7 \pm 1.1$ \\
\hline WM2 & $47.2 \pm 0.7$ & $54.72 \pm 1.5$ & $65.6 \pm 1.7$ \\
\hline WI & $37.31 \pm 0.5$ & $40.1 \pm 1$ & $79 \pm 0.2$ \\
\hline BHT & - & $9.3 \pm 0.1$ & - \\
\hline Ascorbic acid & $5 \pm 0.8$ & $4.4 \pm 0.5$ & - \\
\hline
\end{tabular}

These values are the means of three replicates \pm standard deviation. ABTS - 2,2'-azino-bis(3-ethylbenzothiazoline-6-sulphonic acid; BHT - butylated hydroxytoluene; DPPH - 2,2-diphenyl-1-picrylhydrazyl; GAE - gallic acid equivalents 
Table $2 \mathrm{IC}_{50}(\mu \mathrm{g} / \mathrm{mL})$ of the extracts determined with the MTT assay

\begin{tabular}{lcc}
\hline \multirow{2}{*}{ Extract } & \multicolumn{2}{c}{ IC $_{\mathbf{5 0}}$ values $(\boldsymbol{\mu g} / \mathbf{m L})$} \\
\cline { 2 - 3 } & HepG2 & HUVEC \\
\hline HM1 & $<\mathbf{1 0}$ & $<\mathbf{1 0}$ \\
\hline CM1 & $\mathbf{5 2 . 4 2}$ & $\mathbf{5 1 . 6 3}$ \\
\hline EM1 & $>200$ & $*$ \\
\hline WM1 & $>200$ & $*$ \\
\hline EM2 & $<\mathbf{1 0}$ & $\mathbf{1 1 . 9 6}$ \\
\hline WM2 & $>200$ & $*$ \\
\hline WI & $>200$ & $*$
\end{tabular}

* have not been measured

were more toxic than $\mathrm{CM} 1$, and their toxic concentrations were below the minimum studied concentration. As HepG2 cells have a tumour origin, these active extracts were further investigated on HUVEC cells, which are often used as a model for healthy cells. HM1 was cytotoxic at less than $10 \mu \mathrm{g} / \mathrm{mL}$, while the $\mathrm{IC}_{50}$ of CM1 and EM2 was $51.63 \mu \mathrm{g} /$ $\mathrm{mL}$ and $11.96 \mu \mathrm{g} / \mathrm{mL}$, respectively. Only EM2 was not toxic against HUVEC cells at the concentration cytotoxic for the HepG2 cells. However, it was cytotoxic at the active concentration determined by the antioxidant tests. In contrast, EM1, WM1, WM2, and WI did not exhibit cytotoxic effects at their active antioxidant concentrations.

Extracts with cytotoxic activities were then tested for insecticidal activity (Table 3). HM1 had the highest mortality of $90 \pm 10 \%$ at $5 \mu \mathrm{g}$ per adult mosquito, which was consistent with its cytotoxic activity. However, no extract showed insecticidal activity against the larvae.

Considering the results of all tests, HM1, EM1, and EM2 demonstrated good biological activity and their chemical compositions were determined by GC-MS (for HM1) and LC-MS (for EM1 and EM2). We also determined the content of essential oil obtained by microdistillation of $V$. alliariifolia roots to compare it with the content of HM1.

Tables 4 and 5 show the content of HM1 and the essential oil. The major component in HM1 was isovaleric acid (16\%), which also accounted for $87.3 \%$ of the content detected in the essential oil. Two other major components in HM1 and essential oil were limonene (11.6\%) and 1,8-cineole (2.9\%), respectively. Although plants vary considerably in content with season and locality, we obtained similar findings for essential oil as in our previous study, especially for isovaleric acid (18). This points to a less variable content in $V$. alliariifolia and a possibility of standardised production for the purposes of phytotherapy.

Table 3 HM1, CM1, and EM2 mortality in adult female mosquito Ae. aegypti and $1^{\text {st }}$ instar Ae. aegypti larvae

\begin{tabular}{lccccc}
\hline \multirow{2}{*}{ Code } & Adult female mosquito & \multicolumn{4}{c}{$\mathbf{1}^{\text {st }}$ instar larvae } \\
\cline { 2 - 6 } & $\mathbf{5} \boldsymbol{\mu g}$ per mosquito & $\mathbf{1} \boldsymbol{\mu g} / \boldsymbol{\mu L}$ & $\mathbf{0 . 5} \boldsymbol{\mu g} / \boldsymbol{\mu L}$ & $\mathbf{0 . 2 5} \boldsymbol{\mu g} / \boldsymbol{\mu L}$ & $\mathbf{0 . 1} \boldsymbol{\mu g} / \boldsymbol{\mu L}$ \\
\hline HM1 & $90 \pm 10$ & 0 & 0 & 0 & 0 \\
\hline CM1 & $73.3 \pm 25.2$ & 0 & 0 & 0 & 0 \\
\hline EM2 & $76.7 \pm 15.3$ & 0 & 0 & 0 & 0
\end{tabular}

Positive control permethrin at $6.33 \mathrm{pg} / \mu \mathrm{L}$ resulted in $53 \pm 11 \%$ mortality and at $47.4 \mathrm{pg} / \mu \mathrm{L}$ resulted in $100 \pm 0 \%$ mortality. No mortality was observed in negative control and solvent control (DMSO) groups

Table 4 Composition of the extract HM1-SPME

\begin{tabular}{lccc}
\hline RRI & Main compounds & $\mathbf{\%}$ & Identification method \\
\hline 1203 & Limonene & $\mathbf{1 1 . 6}$ & $\mathrm{t}_{\mathrm{R}}, \mathrm{MS}$ \\
\hline 1280 & $\boldsymbol{p}$-Cymene & $\mathbf{8 . 7}$ & $\mathrm{t}_{\mathrm{R}}, \mathrm{MS}$ \\
\hline 1400 & Tetradecane & 1.1 & $\mathrm{t}_{\mathrm{R}}, \mathrm{MS}$ \\
\hline 1412 & $($ E)-2-Hexenol & 7.2 & $\mathrm{MS}$ \\
\hline 1474 & Acetic acid & 1.4 & $\mathrm{MS}$ \\
\hline 1495 & 2-Ethyl hexanol & $\mathbf{1 0 . 4}$ & $\mathrm{MS}$ \\
\hline 1532 & Camphor & 1.2 & $\mathrm{t}_{\mathrm{R}}, \mathrm{MS}$ \\
\hline 1565 & Linalool & 5.6 & $\mathrm{t}_{\mathrm{R}}, \mathrm{MS}$ \\
\hline 1684 & Linalyl acetate & 4.0 & $\mathrm{MS}$ \\
\hline 1707 & Isovaleric acid & $\mathbf{1 6 . 0}$ & $\mathrm{MS}$ \\
\hline 1804 & $\alpha-$-Terpinyl acetate & 2.3 & $\mathrm{MS}$ \\
\hline 1882 & Cumin aldehyde & 1.1 & $\mathrm{t}_{\mathrm{R}}, \mathrm{MS}$ \\
\hline 2246 & Carvacrol & 2.4 & $\mathrm{MS}$ \\
\hline
\end{tabular}

Major compounds are in bold. RRI - relative retention indices experimentally calculated against $n$-alkanes; $\mathrm{t}_{\mathrm{R}}-$ based on relative retention indices of authentic compounds on a HP Innowax column; MS - based on computer matching of the mass spectra with those of the Baser Library of Essential Oil Constituents, Adams library (40), MassFinder library (41), and Wiley library (42) 


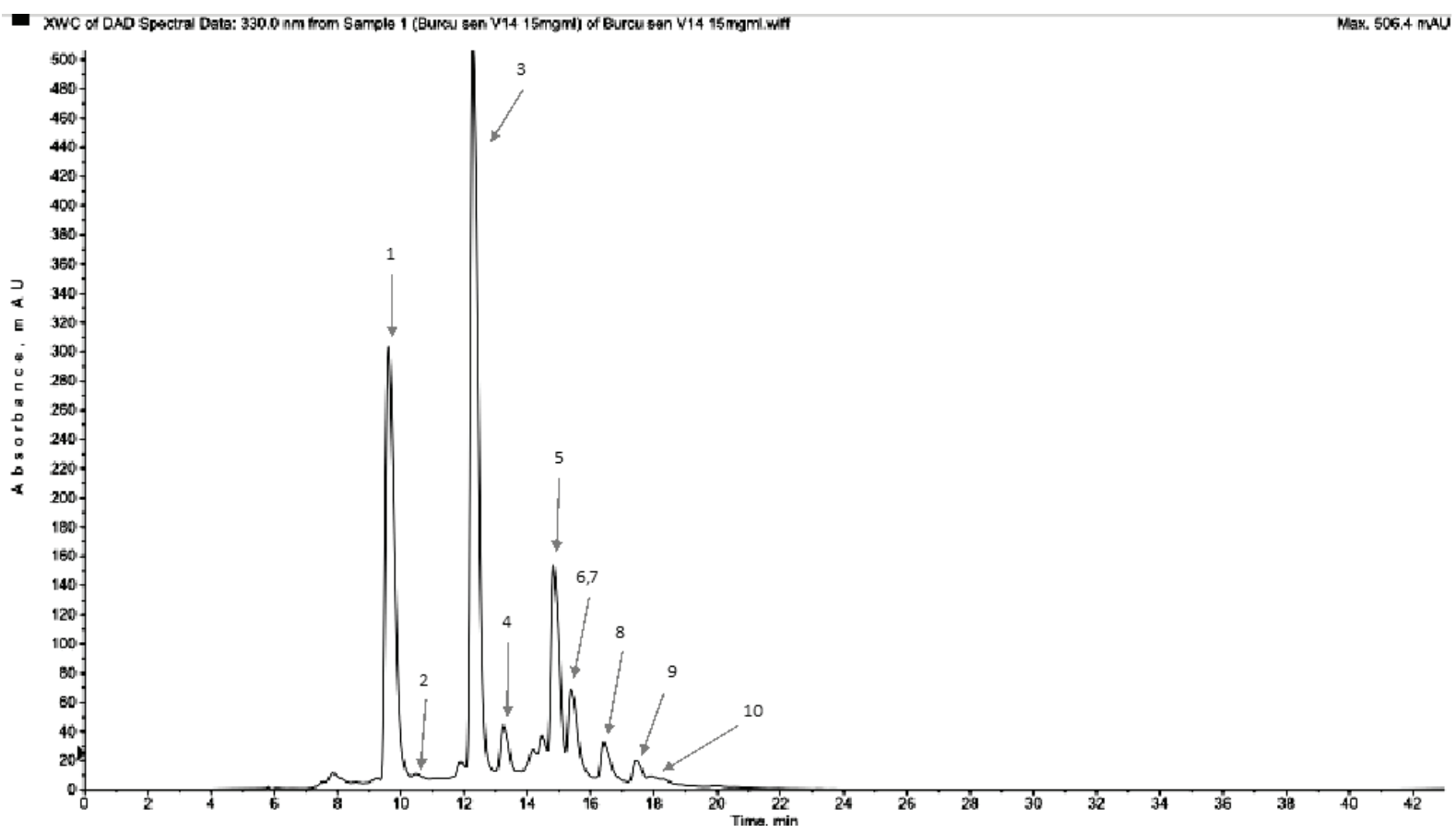

Figure 1 LC-MS chromatogram of EM1; 1: 5-O-Caffeoylquinic acid; 3: Verbascoside; 5: Hesperidin; 6: 3,5-Dicaffeoylquinic acid; 7 : Dicaffeoylquinic acid (substituted at position 4); 8: Methylquercetin rutinoside; 2,4,9,10: unknown compounds

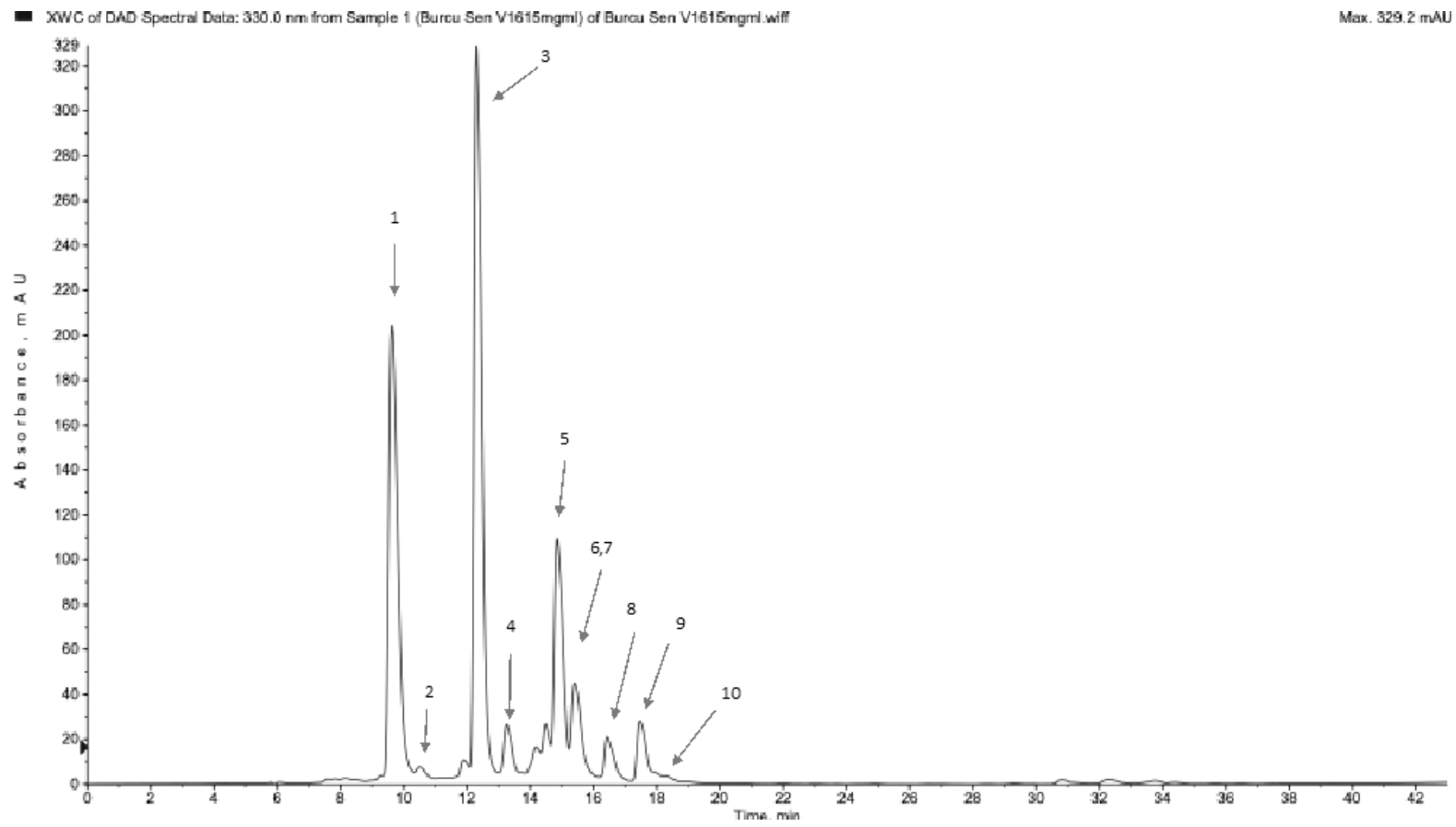

Figure 2 LC-MS chromatogram of EM2; 1: 5-O-Caffeoylquinic acid; 3: Verbascoside; 5: Hesperidin; 6: 3,5-Dicaffeoylquinic acid; 7 : Dicaffeoylquinic acid (substituted at position 4); 8: Methylquercetin rutinoside; 2,4,9,10: unknown compounds 
Table 5 Composition of the essential oil obtained by microdistillation of $V$. alliariifolia roots

\begin{tabular}{|c|c|c|c|}
\hline RRI & Compounds & $\%$ & Identification method \\
\hline 1213 & 1,8-Cineole & 2.9 & $\mathrm{t}_{\mathrm{R}}, \mathrm{MS}$ \\
\hline 1516 & Theaspirane A & 0.3 & MS \\
\hline 1532 & Camphor & 1.2 & $\mathrm{t}_{\mathrm{R}}, \mathrm{MS}$ \\
\hline 1553 & Linalool & \multirow{2}{*}{0.8} & $\mathrm{t}_{\mathrm{R}}, \mathrm{MS}$ \\
\hline 1556 & Theaspirane B & & MS \\
\hline 1565 & Linalyl acetate & 0.3 & MS \\
\hline 1590 & Bornyl acetate & 0.4 & $\mathrm{t}_{\mathrm{R}}, \mathrm{MS}$ \\
\hline 1684 & Isovaleric acid & 87.3 & MS \\
\hline 1706 & $\alpha$-Terpineol & 0.3 & $\mathrm{t}_{\mathrm{R}}, \mathrm{MS}$ \\
\hline 1718 & Borneol & 0.5 & $\mathrm{t}_{\mathrm{R}}, \mathrm{MS}$ \\
\hline 1755 & Carvone & 0.3 & $\mathrm{t}_{\mathrm{R}}, \mathrm{MS}$ \\
\hline 1815 & Valeric acid & 1.0 & MS \\
\hline 1871 & Hexanoic acid & 0.1 & MS \\
\hline 2012 & Maaliol & 0.2 & MS \\
\hline 2084 & Octanoic acid & $\operatorname{tr}$ & MS \\
\hline 2144 & Spathulenol & 0.3 & $\mathrm{t}_{\mathrm{R}}, \mathrm{MS}$ \\
\hline 2174 & Nonanoic acid & 0.2 & MS \\
\hline 2191 & $\gamma$-Eudesmol & 0.2 & MS \\
\hline 2204 & Thymol & 0.3 & $\mathrm{t}_{\mathrm{R}}, \mathrm{MS}$ \\
\hline 2246 & Carvacrol & 1.3 & $\mathrm{t}_{\mathrm{R}}, \mathrm{MS}$ \\
\hline 2247 & $\alpha$-Eudesmol & 0.2 & MS \\
\hline 2255 & $\beta$-Eudesmol & 0.3 & MS \\
\hline 2273 & Selin-11-en-4 $\alpha$-ol & 0.8 & MS \\
\hline
\end{tabular}

The major compound is written in bold. RRI - relative retention indices calculated against $n$-alkanes; $\%$ - calculated from FID chromatograms; $\operatorname{tr}$ - trace $(<0.1 \%) ; \mathrm{t}_{\mathrm{R}}$ - based on the retention times of genuine compounds on the HP Innowax column; MS - based on computer matching of the mass spectra with those of the Baser Library of Essential Oil Constituents, Adams library [40], MassFinder library [41], and Wiley library [42] and comparison with literature RRIs

Judging by LC-MS, EM1 and EM2 had the same chemical composition dominated by 5-O-caffeoylquinic acid (aka chlorogenic acid), verbascoside, and 3,5-dicaffeoylquinic acid (Figures 1 and 2, Table 6). Even though EM1 content dominated over EM2 in terms of compounds found, it was less active. This again suggests that nonpolar compounds in EM2 are more cytotoxic.

Compounds with high antioxidant activity in EM1 and EM2 extracts, namely verbascoside, hesperidin, caffeoylquinic acid analogues (5-O-caffeoylquinic acid and 3,5-dicaffeoylquinic acid), and methylquercetin analogues, have already been investigated and their antioxidant activities reported in earlier studies. Verbascoside was reported for high scavenger activity (48) and good antioxidant effect with other phenolic compounds (49). Funes et al. (50) found a correlation between plasma verbascoside levels and plasma antioxidant capacity in rats treated with lemon verbena extract. Another study (51) identified 3,5-di- $O$-caffeoylquinic acid as a good radical scavenger $\left(\mathrm{IC}_{50} 18.2 \mu \mathrm{mol} / \mathrm{L}\right)$. High antioxidant effect was also reported for chlorogenic acid $\left(\mathrm{IC}_{50} 6.35 \mu \mathrm{mol} / \mathrm{L}\right)$ in Eriobotrya japonica Lindl. extracts (52).
Flavonoids have a large spectrum of activities, and some are known for their high bioactivities. Flavonoid hesperidin, for example, was reported for strong antioxidant and protective effect against cell damage (53). Methylquercetin derivatives in Halimodendron halodendron (Pall.) Voss also showed high antioxidant activity $\left(\mathrm{IC}_{50} 7.2-216.7 \mu \mathrm{g} / \mathrm{mL}\right)$ (54).

Isovaleric acid, limonene, $p$-cymene, carvacrol, and linalool identified in active nonpolar extracts in our study have also been described by other authors. Using the MTT assay, Scragg et al. (55) found that isovaleric acid and valeric acid reduced the metabolic activity of Vero cells. The same method was used to assess the cytotoxic effects of tinctures prepared from the rhizomes and roots of $V$. officinalis L., $V$. wallichii DC. (V. jatamansi), and $V$. edulis Nutt. ex Torr \& Gray ssp. procera (H.B.K.) F. G. Meyer ( $V$. mexicana DC.) and their constituents in human small-cell lung cancer (GLC4) and human colorectal cancer (COLO320) cell lines. The diene type valepotriates (acetovaltrate, isovaltrate, and valtrate) were two to three times more toxic than valepotriates of the monoene type (didrovaltrate and isovaleroxyhydroxydidrovaltrate). In addition, valerenic acids (valerenic acid, acetoxyvalerenic 
acid, and hydroxyvalerenic acid) and methyl valerenate, which are characteristic compounds of $V$. officinalis, had a low cytotoxicity $\left(\mathrm{IC}_{50}\right.$ values between 100 and $\left.200 \mu \mathrm{mol} / \mathrm{L}\right)$ (56).

Russo et al. (57) have suggested that monoterpenes such as limonene have a role in cancer cell death induced by Citrus bergamia Risso essential oil. Manassero et al. (58) compared the growth inhibition potential of the essential oil of mandarin peel and its major component limonene on two human tumour cell lines (lung adenocarcinoma A549 and hepatocarcinoma HepG2) and established that the essential oil was more effective than limonene alone, which points to an additive or synergistic effect of limonene when combined with minor oil components. In line with these findings, a recent investigation (59) also suggests that essential oils rich in limonene, especially the essential oil from unripe Citrus reticulata Blanco fruit peels (93.71\% of limonene) are highly cytotoxic to human lung carcinoma (A549), human colon carcinoma (HCT116), and hepatocellular carcinoma (HepG2) cells. Sivropoulou et al. (60) reported that the essential oil from Origanum vulgare subsp. hirtum, whose major constituents were carvacrol, p-cymene, and thymol, elicited high cytotoxic effect against human laryngeal carcinoma (Hep-2) cells, human cervical carcinoma (HeLa) cells, kidney epithelial cells from African green monkey (Vero), and rabbit skin (RSC) cells. In another study (61), carvacrol showed high dose-dependent cytotoxicity against two human cervical carcinoma cell lines (HeLa and $\mathrm{SiHa}$ ) at $\mathrm{IC}_{50}$ of $50 \mathrm{mg} / \mathrm{L}$, while in combination with thymol it was more active against human epithelial colorectal adenocarcinoma cells (Caco-2 cells) compared to single constituents (62).

Coccimiglio et al. (63) evaluated the cytotoxic effects of Origanum vulgare extract components and their combinations (carvacrol/thymol, carvacrol/thymol/ $p$ cymene) on A549 cells. The extract was the most cytotoxic, followed by the combinations (especially carvacrol/ thymol $/ p$-cymene) and finally single components. Clearly, the cytotoxic effects increase with the number of active components in the combination. Al-Fatlawi et al. (64) investigated mechanisms behind carvacrol cytotoxicity in human breast adenocarcinoma (MCF-7) cell line and found that this compound inhibited the cell growth and induced the apoptosis regulating genes.

Linalool contained in the essential oils from five Lamiaceae species showed cytotoxicity on amelanotic melanoma and renal cell adenocarcinoma $\left(\mathrm{IC}_{50}\right.$ values $23.16 \mu \mathrm{g} / \mathrm{mL}$ and $23.77 \mu \mathrm{g} / \mathrm{mL}$, respectively) (65).

According to our findings, the essential oil of $V$. alliariifolia and HM1 differed only in the presence of 1.8-cineole (eucalyptol). Sampath et al. (66) evaluated the cytotoxicity of extracts prepared from Callistemon citrinus (Curtis.) Skeels and found that the 1,8-cineole-containing hexane extract has a potential as anticancer agent. These outcomes speak in favour of our observations regarding the higher cytotoxicity of the $V$. alliariifolia essential oil.

Besides volatile and nonpolar compounds, active extracts (EM1 and EM2) in our study contained verbascoside, chlorogenic acid, hesperidin and methylquercetin rutinoside. Saracoglu et al. (67) investigated the cytostatic and cytotoxic activities of compounds isolated from Phlomis armeniaca Willd. and Scutellaria salviifolia Bentham. Verbascoside showed good cytotoxicity in rat hepatocellular carcinoma (dRLh-84) cell line at $\mathrm{IC}_{50}$ of $61.98 \mu \mathrm{g} / \mathrm{mL}$ and was the most active compound against murine sarcoma cancer (S-180) cell line. It also elicited cytotoxic effects in HeLa and murine leukaemia (P-388) cell lines, but was not toxic against hepatocytes (67). In addition to this, verbascoside was reported active against HepG2, MCF-7, and human rhabdomyosarcoma (RD) cell lines (68).

Jiang et al. (69) found that chlorogenic acid elicited a cytotoxic effect on human oral squamous cell carcinoma (HSC-2) and salivary gland tumour (HSG) cells at millimolar concentrations.

Speaking of the cytotoxic potential of flavonoids relevant for Valeriana alliariifolia, we have to mention hesperidin. It was reported cytotoxic against MCF-7 cells (70), and induced apoptosis in HepG2 cells (71). Methylquercetin was reported for antimigration and antiproliferative activities(72), while Sak et al. (73) reported high cytotoxicity of its analogues 3'-O-methylquercetin

Table 6 Composition of EM1 and EM2

\begin{tabular}{|c|c|c|c|c|}
\hline Rt (min) & {$[\mathrm{M}-\mathrm{H}]^{-}$} & MS $^{2}$ & Identification & Reference \\
\hline 9.9 & 353 & 191 & 5-O-Caffeoylquinic acid & {$[44]$} \\
\hline 10.6 & 435 & 389,227 & Unknown & - \\
\hline 12.2 & 623 & $461,315,179,161$ & Verbascoside & [43] \\
\hline 13.2 & 507 & $461,359,179$ & Unknown & - \\
\hline 15.0 & 609 & $343,325,301,286$ & Hesperidin & {$[45]$} \\
\hline 15.2 & 515 & $353,191,179,135$ & 3,5-Dicaffeoylquinic acid & [46] \\
\hline 15.3 & 515 & $353,299,173$ & Dicaffeoylquinic acid (subsituated at position 4) & {$[46]$} \\
\hline 16.5 & 623 & $339,315,300,271$ & Methylquercetin rutinoside & {$[47]$} \\
\hline 17.9 & 769 & $666,571,511,487,427,145$ & Unknown & - \\
\hline 18.1 & 595 & 327,285 & Unknown & - \\
\hline
\end{tabular}

The major compounds are written in bold 
and 4'-O-methylquercetin against A549 and HCC-44 cell lines. Both analogues exhibited higher activity $\left(\mathrm{IC}_{50}\right.$ of $26.6 \mu \mathrm{mol} / \mathrm{L}$ and $19.6 \mu \mathrm{mol} / \mathrm{L}$ against $\mathrm{A} 549$ and $15.9 \mu \mathrm{mol} / \mathrm{L}$ and $20.3 \mu \mathrm{mol} / \mathrm{L}$ against $\mathrm{HCC}-44$, respectively) than quercetin $(72.2 \mu \mathrm{mol} / \mathrm{L}$ and $107.6 \mu \mathrm{mol} / \mathrm{L}$, respectively). They induced apoptosis in both cell lines by activating effector caspase-3. These findings suggest that methylation of quercetin has a role in the cytotoxicity.

We would also like to briefly discuss the insecticidal activity of the studied Valeriana extracts, which can be associated with their specific constituents, limonene in particular. Chantraine et al. (74) reported $90 \%$ mortality of limonene at $100 \mathrm{mg} / \mathrm{mL}$ against Aedes aegypti larvae and $60 \%$ mortality at $50 \mathrm{mg} / \mathrm{mL}$. However, 1,8-cineole, linalool, terpinen-4-ol and $\alpha$-terpineol had no insecticidal effect. Santos et al. (75) reported that both R- and S-limonene isomers elicited the highest larvicidal activity ( $\mathrm{LC}_{50} 0.027$ and $0.03 \mathrm{mg} / \mathrm{mL}$, respectively). Silva et al. (76) reported that limonene also had the highest larvicidal activity at low concentration $\left(\mathrm{IC}_{50} 0.037 \mathrm{mg} / \mathrm{mL}\right)$, followed by carvacrol and thymol $\left(\mathrm{IC}_{50} 0.070\right.$ and $0.079 \mathrm{mg} / \mathrm{mL}$, respectively) (76).

\section{CONCLUSION}

In the light of our findings and available literature, we can conclude that root extracts of Valeriana alliariifolia have a good bioactive potential that could be used for different purposes, including the development of new agents for the treatment of various diseases. Isovaleric acid, limonene, carvacrol, $p$-cymene, thymol, linalool, verbascoside, chlorogenic acid, hesperidin, and methylquercetin rutinoside showed cytotoxic potential, and limonene, 1,8-cineol, carvacrol, and thymol the insecticidal one.

The difference in content between the essential oil and HM1 was remarkable. It suggests that the variability observed in the activity of the samples was a result of composition and that, therefore, the aim of treatment should dictate which type of preparation is to be selected.

An added value of our study is that it determined verbascoside and methylquercetin rutinoside for the first time in the Valeriana extracts. This finding is particularly important for planning and conducting future studies with the Valeriana species.

\section{Acknowledgments}

All authors thank the City of Trabzon Governor's Office, Turkish Ministry of Agriculture and Forestry, Trabzon Directorate of Provincial Agriculture and Forestry, Zehra Ozturk, and Oguzhan Baci for useful support in the field.

This study was partly funded by the Deployed WarFighter Protection Research Program grants from the US Department of Defense Armed Forces Pest Management Board.

\section{REFERENCES}

1. Richardson IBK. Valeriana. In: Davis PH, editor. Flora of Turkey and the East Aegean islands. Vol. 4. Edinburgh: Edinburgh University Press; 1972. p. 551-8.

2. Davis PH, editor. Flora of Turkey and the East Aegean islands. Vol. 10. Supplement I. Edinburgh: Edinburgh University Press; 1988.

3. Güner A, Özhatay N, Ekim T, Başer KHC, editors. Flora of Turkey and the east aegean islands. Vol. 11. Edinburgh: Edinburgh University Press; 2008.

4. Taherpour AA, Maroofi H, Bajelani O, Larijani K. Chemical composition of the essential oil of Valeriana alliariifolia Adams of Iran. Nat Prod Res 2010;24:973-8. doi: 10.1080/14786410902900010

5. Aslan S. Valeriana L. In: Güner A, Aslan S, Ekim T, Vural M, Babac MT, editors. Turkiye bitkileri listesi (damarli bitkiler) [List of Turkish Flora (vascular plants), in Turkish]. Istanbul: Nezahat Gokyigit Botanik Bahcesi ve Flora Arastirmalari Dernegi Yayini; 2012. p. 322-5.

6. Baytop T. Türkiye'de Bitkiler Ile Tedavi (Geçmişte ve Bugün) [Therapy with medicinal plants in Turkey (past and present), in Turkish]. Istanbul: Nobel Tip Kitapevleri Ltd Sti; 1999.

7. Bos R, Woerdenbag HJ, van Putten FMS, Hendriks H, Scheffer JJC. Seasonal variation of the essential oil, valerenic acid and derivatives, and velopotriates in Valeriana officinalis roots and rhizomes, and the selection of plants suitable for phytomedicines. Planta Med 1998;64:143-7. doi: 10.1055/s2006-957392

8. Wang Y, Jin L, Yu S, Shi Q, Gu Y, Kiyota H. Chemical constituents of plants from the genus Valeriana. Mini-Rev Org Chem 2010;7:161-72. doi: 10.2174/157019310791065537

9. Şen B, Mat A. Chemical and medicinal evaluations of the Valeriana species in Turkey. J Fac Pharm Istanbul 2015;45:267-76.

10. Xu K, Lin Y, Zhang R, Lan M, Chen C, Li S, Zuo C, Chen C, Zhang T, Yan Z. Evaluation of safety of iridoids rich fraction from Valeriana jatamansi Jones: Acute and subchronic toxicity study in mice and rats. J Ethnopharmacol 2015;172:386-94. doi: 10.1016/j.jep.2015.06.046

11. Aydın F, Yurdakok Dikmen B, Kismali G. The potential cytotoxic effects of Valeriana officinalis extract on prostate cancer cell lines DU-145 and PC-3. Toxicol Lett 2016;258(Supplement):S299. doi: 10.1016/j. toxlet.2016.06.2037

12. Lin S, Zhang Z-X, Chen T, Ye J, Dai W-X, Shan L, Su J, Shen Y-H, Li H-L, Liu R-H, Xu X-K, Wang H, Zhang W-D. Characterization of chlorinated valepotriates from Valeriana jatamansi. Phytochemistry 2013;85:185-93. doi: 10.1016/j. phytochem.2012.08.015

13. Wang R-J, Chen H-M, Yang F, Deng Y, Ao H, Xie X-F, Li H-X, Zhang H, Cao Z-X, Zhu L-X, Chen Y, Peng C, Tan Y-Z. Iridoids from the roots of Valeriana jatamansi Jones. Phytochemistry 2017;141:156-61. doi: 10.1016/j. phytochem.2017.05.010

14. Kırmızıbekmez H, Kúsz N, Bérdi P, Zupkó I, Hohmann J. New iridoids from the roots of Valeriana dioscoridis Sm. Fitoterapia 2018;130:73-8. doi: 10.1016/j.fitote.2018.08.007

15. Liu Y-H, Wu P-Q, Hu Q-L, Pei Y-J, Qi F-M, Zhang Z-X, Fei D-Q. Cytotoxic and antibacterial activities of iridoids and sesquiterpenoids from Valeriana jatamansi. Fitoterapia 2017;123:73-8. doi: 10.1016/j.fitote.2017.09.011 
16. Dua, VK, Alam MF, Pandey AC, Rai S, Chopra AK, Kaul VK, Dash AP. Insecticidal activity of Valeriana jatamansi (Valerianaceae) Against Mosquitoes. J Am Mosq Control Assoc 2008;24:315-8. doi: 10.2987/5642.1

17. Tan Y-Z, Yong Y, Dong Y-H, Wang R-J, Li H-X, Zhang H, Guo D-L, Zhang S-J, Dong X-P, Xie X-F. A new secoiridoid glycoside and a new sesquiterpenoid glycoside from Valeriana jatamansi with neuroprotective activity. Phytochem Lett 2016;17:177-80. doi: 10.1016/j.phytol.2016.07.020

18. Bardakçı H, Demirci B, Yeşilada E, Kırmızıbekmez H, Başer, KHC. Chemical composition of the essential oil of the subterranean parts of Valeriana alliariifolia. Rec Nat Prod 2012;6:89-92.

19. Özgökçe F. Özçelik H. Ethnobotanical aspects of some Anatolia, Turkey. Econ Bot 2004;58:697-704. doi: 10.1663/0013-0001(2004) 058[0697:EAOSTI]2.0.CO;2

20. Oz-Aydın S, Dirmenci T, Tumen G, Başer KHC. Plants used as analgesic in the folk medicine of Turkey. In: Ertug ZF, editor. Proceedings of the $\mathrm{IV}^{\mathrm{th}}$ International Congress of Ethnobotany (ICEB, 2005); 21-26 August 2005; Istanbul, Turkey. Istanbul: Yeditepe University; 2006. p. 167-71.

21. Fakir H, Korkmaz M, Güller B. Medicinal plant diversity of western Mediterranean region in Turkey. JABS 2009;3:33-43.

22. Kaya DA. [Çukurova bölgesinde farklı sıra arası ve hasat zamanlarında kediotu (Valeriana officinalis L.) bitkisinin verim ve uçucu yağ kalitesinin araştırılması, in Turkish]. [PhD Thesis]. Adana: Cukurova University; 2006.

23. Özbay O, Aslan S, Kartal M, Kurucu S, Bos R, Woerdenbag HJ, Kayser O. Preliminary examination of the composition of the essential oil from the roots and rhizomes of Valeriana alpestris Stev. growing in Turkey. J Essent Oil Res 2009;21:555-7. doi: 10.1080/10412905.2009.9700243

24. Aslan S, Kartal M, Kurucu S, Kuiper JM, Kruizinga WH, Bos R, Woerdenbag HJ, Kayser O. Composition of the essential oil from roots and rhizomes of Valeriana phu L. growing wild in Turkey. J Essent Oil Res 2009;21:437-40. doi: 10.1080/10412905.2009.9700212

25. Ebrahimzadeh H, Radjabian T, Tousi AE, Nikham V, Mozaffarian V. Evaluation of some Iranian wild species from Valerianaceae as commercial sources of valepotriates. J Biol Sci 2008;8:549-55. doi: 10.3923/jbs.2008.549.555

26. Samaneh ET, Tayebeh R, Hassan E, Vahid N. Composition of essential oils in subterranean organs of three species of Valeriana L. Nat Prod Res 2010;24:1834-42. doi: 10.1080/14786419.2010.482051

27. Ozdemir A, Turkoglu V, Demir H. In vitro effect of some plant extracts on acetylcholinesterase enzyme in human erythrocytes and serum. Fresen Environ Bull 2013;22:2510-5.

28. Karadeniz A, Çinbilgel I, Gün SŞ, Çetin A. Antioxidant activity of some Turkish medicinal plants. Nat Prod Res 2015;29:2308-12. doi: 10.1080/14786419.2015.1005618

29. Fu W, Chen J, Cai Y, Lei Y, Chen L, Pei L, Zhou D, Liang $\mathrm{X}$, Ruan J. Antioxidant, free radicalscavenging, antiinflammatory and hepatoprotective potential of the extract from Parathelypteris nipponica (Franch.et Sav.) Ching. J Ethnopharmacol 2010;130:521-8. doi: 10.1016/j. jep.2010.05.039

30. Re R, Pellegrini N, Proteggente A, Pannala A, Yang M, RiceEvans C. Antioxidant activity applying an improved ABTS radical cation decolorization assay. Free Radic Biol Med 1999;26:1231-7. doi: 10.1016/s0891-5849(98)00315-3
31. Taşkın T, Çam ME, Taşkın D, Rayaman E. In vitro and In vivo biological activities and phenolic characterization of Thymus praecox subsp. skorpilii var. skorpilii. J Food Meas Charact 2019;13:536-44. doi: 10.1007/s11694-018-9967-1

32. Şen B, Kessler S, Gürdal B, Kiemer A, Mat A. The difference between the extracts of Erica manipuliflora in flowering and fruiting periods in terms of the cytotoxic effects. J Fac Pharm Istanbul Univ 2016;46:71-8.

33. Kessler SM, Pokorny J, Zimmer V, Laggai S, Lammert F, Bohle RM, Kiemer AK. IGF2 mRNA binding protein p62/ IMP2-2 in hepatocellular carcinoma: antiapoptotic action is independent of IGF2/PI3K signaling. Am J Physiol Gastrointest Liver Physiol 2013;304:G328-36. doi: 10.1152/ ajpgi.00005.2012

34. Kiemer AK, Weber NC, Fürst R, Bildner N, Kulhanek-Heinze S, Vollmar AM. Inhibition of p38 MAPK Activation via Induction of MKP-1: atrial natriuretic peptide reduces TNF$\alpha$ - induced actin polymerization and endothelial permeability. Circ Res 2002;90:874-81. doi: 10.1161/01. res.0000017068.58856.f3

35. Diesel B, Ripoche N, Risch RT, Tierling S, Walter J, Kiemer AK. Inflammation-induced up-regulation of TLR2 expression in human endothelial cells is independent of differential methylation in the TLR2 promoter CpG island. Innate Immun 2011;18:112-23. doi: 10.1177/1753425910394888

36. Mosmann T. Rapid colorimetric assay for cellular growth and survival: application to proliferation and cytotoxicity assays. J Immunol Methods 1983;65:55-63. doi: 10.1016/0022-1759(83)90303-4

37. Tabanca N, Bernier UR, Agramonte NM, Tsikolia M, Bloomquist JR. Discovery of repellents from natural products. Curr Org Chem 2016;20:2690-702. doi: 10.2174/ 1385272820666160421151503

38. Pridgeon JW, Pereira RM, Becnel JJ, Allan SA, Clark GG, Linthicum KJ. Susceptibility of Aedes aegypti, Culex quinquefasciatus Say, and Anopheles quadrimaculatus Say to 19 pesticides with different modes of action. J Med Entomol 2008;45:82-7. doi: 10.1093/jmedent/45.1.82

39. Masi M, Cimmino A, Tabanca N, Becnel JJ, Bloomquist JR, Evidente A. A survey of bacterial, fungal and plant metabolites against Aedes aegypti (Diptera: Culicidae), the vector of yellow and dengue fevers and Zika virus. Open Chem 2017;15:156-66. doi: 10.1515/chem-2017-0019

40. Adams RP. Identification of Essential Oil Components by Gas Chromatography/Mass Spectrometry. $4^{\text {th }}$ ed. Carol Stream (IL): Allured Publishing Corporation; 2007.

41. Hochmuth DH. MassFinder-4. Hamburg: Hochmuth Scientific Consulting; 2008.

42. McLafferty FW, Stauffer DB. The Wiley/NBS Registry of Mass Spectral Data. New York: J. Wiley and Sons; 1989.

43. Göger F, Köse YB, Göger G, Demirci F. Phytochemical characterization of phenolics by LC-MS/MS and biological evaluation of Ajuga orientalis from Turkey. Bangladesh J Pharmacol 2015;10:639-44. doi: 10.3329/bjp.v10i3.23500

44. Navarrete A, Avula B, Choi Y-W, Khan IA. Chemical fingerprinting of Valeriana species: simultaneous determination of valerenic acids, flavonoids, and phenylpropanoids using liquid chromatography with ultraviolet detection. J AOAC Int 2006;89:8-15. PMID: 16512222

45. Marder M, Viola H, Wasowski C, Fernández S, Medina JH, Paladini AC. 6-Methylapigenin and hesperidin: new 
Valeriana flavonoids with activity on the CNS. Pharmacol Biochem Behav 2003;75:537-45. doi: 10.1016/s00913057(03)00121-7

46. Meinhart AD, Damin FM, Caldeirão L, da Silveira TFF, Filho JT, Godoy HT. Chlorogenic acid isomer contents in 100 plants commercialized in Brazil. Food Res Int 2017;99:522-30. doi: 10.1016/j.foodres.2017.06.017

47. Helmja K. Determination of phenolic compounds and their antioxidative capability in plant extracts. [ $\mathrm{PhD}$ thesis] Tallinn: Tallinn University of Technology; 2010.

48. Wang P, Kang J, Zheng R, Yang Z, Lu J, Gao J, Jia, Z. Scavenging effects of phenylpropanoid glycosides from Pedicularis on superoxide anion and hydroxyl radical by Spin trapping method(95)02255-4. Biochem Pharmacol 1996;51:687-91. doi: 10.1016/S0006-2952(95)02255-4

49. Aleo E, Ricci R, Passi S, Cataudella S. A novel cyt C- $\mathrm{H}_{2} \mathrm{O}_{2}$ chemiluminescence assay for measuring the reducing/ antioxidant capacity of a wide range of hydrophilic and lipophilic antioxidants and biological samples. Prog Nutr 2005;3:154-82.

50. Funes L, Fernández-Arroyo S, Laporta O, Pons A, Roche E, Segura-Carretero A, Fernández-Gutiérrez A, Micol V. Correlation between plasma antioxidant capacity and verbascoside levels in rats after oral administration of lemon verbena extract. Food Chem 2009;117:589-98. doi 10.1016/j.foodchem.2009.04.059

51. Hung TM, Na M, Thuong PT, Su ND, Sok D, Song KS, Seong $\mathrm{YH}$, Bae K. Antioxidant activity of caffeoyl quinic acid derivatives from the roots of Dipsacus asper Wall. J Ethnopharmacol 2006;108:188-92. doi: 10.1016/j. jep.2006.04.029

52. Jung HA, Park JC, Chung HY, Kim J, Choi JS. Antioxidant flavonoids and chlorogenic acid from the leaves of Eriobotrya japonica. Arch Pharm Res 1999;22:213-8. doi: 10.1007/ BF02976549

53. Wilmsen PK, Spada DS, Salvador M. Antioxidant activity of the flavonoid hesperidin in chemical and biological systems. J Agric Food Chem 2005;53:4757-61. doi: 10.1021/ jf0502000

54. Wang J, Lou J, Luo C, Zhou L, Wang M, Wang L. Phenolic compounds from Halimodendron halodendron (Pall.) voss and their antimicrobial and antioxidant activities. Int J Mol Sci 2012;13:11349-64. doi: 10.3390/ijms130911349

55. Scragg MA, Cannon SJ, Williams DM. Comparative cytotoxic effects of short-chain fatty acids produced by periodontal pathogens on two cultured fibroblast line. Microb Ecol Health Dis 1994;7:83-90. doi : 10.3109/08910609409141576

56. Bos R, Hendriks H, Scheffer JJC, Woerdenbag HJ. Cytotoxic potential of valerian constituents and valerian tinctures. Phytomedicine 1998;5:219-25. doi: 10.1016/S09447113(98)80032-9

57. Russo R, Ciociaro A, Berliocchi L, Cassiano MG, Rombolà L, Ragusa S, Bagetta G, Blandini F, Corasaniti MT. Implication of limonene and linalyl acetate in cytotoxicity induced by bergamot essential oil in human neuroblastoma cells. Fitoterapia 2013;89:48-57. doi: $10.1016 / \mathrm{j}$. fitote.2013.05.014

58. Manassero CA, Girotti JR, Mijailovsky S, García de Bravo M, Polo M. In vitro comparative analysis of antiproliferative activity of essential oil from mandarin peel and its principal component limonene. Nat Prod Res 2013;27:1475-8. doi: 10.1080/14786419.2012.718775

59. Al-Gendy AA, El-Sayed MA, Hamdan DI, El-Shazly AM. Volatile constituents, antimicrobial and cytotoxic activities of citrus reticulata Blanco Cultivar Murcott. Int J Pharmacogn Phytochem 2017;9:376-86. doi: 10.25258/phyto.v9i2.8089

60. Sivropoulou A, Papanikolaou E, Nikolaou C, Kokkini S, Lanaras T, Arsenakis M. Antimicrobial and cytotoxic activities of Origanum essential oils. J Agric Food Chem 1996;44:1202-5. doi: 10.1021/jf950540t

61. Mehdi SJ, Ahmad A, Irshad M, Manzoor N, Rizvi MMA. Cytotoxic effect of carvacrol on human cervical cancer cells. Biol Med 2011;3:307-12. doi: 10.4172/0974-8369.10000119

62. Llana-Ruiz-Cabello M, Gutiérrez-Praena D, Pichardo S, Moreno FJ, Bermúdez JM, Aucejo S, Cameán AM. Cytotoxicity and morphological effects induced by carvacrol and thymol on the human cell line Caco-2. Food Chem Toxicol 2014;64:281-90. doi: 10.1016/j.fct.2013.12.005

63. Coccimiglio J, Alipour M, Jiang ZH, Gottardo C, Suntres Z. Antioxidant, antibacterial, and cytotoxic activities of the ethanolic Origanum vulgare extract and its major constituents. Oxid Med Cell Longev 2016;2016:ID1404505. doi: 10.1155/2016/1404505

64. Al-Fatlawi AA, Rahisuddin, Ahmad A. Cytotoxicity and pro-apoptotic activity of carvacrol on human breast cancer cell line MCF-7. World J Pharm Sci 2014;2:1218-23.

65. Loizzo MR, Tundis R, Menichini F, Saab AM, Statti GA, Menichini F. Cytotoxic activity of essential oils from labiatae and lauraceae families against in vitro human tumor models. Anticancer Res 2007;27(5A):3293-9. PMID: 17970073

66. Sampath S, Veeramani V, Krishnakumar GS, Sivalingam U, Madurai SL, Chellan R. Evaluation of in vitro anticancer activity of 1,8-cineole-containing $n$-hexane extract of Callistemon citrinus (Curtis) Skeels plant and its apoptotic potential. Biomed Pharmacother 2017;93:296-307. doi: 10.1016/j.biopha.2017.06.056

67. Saracoglu I, Inoue M, Calis I, Ogihara Y. Studies on constituents with cytotoxic and cytostatic activity of two Turkish medicinal plants Phlomis armeniaca and Scutellaria salviifolia. Biol Pharm Bull 1995;18:1396-400. doi: 10.1248/ bpb.18.1396

68. Harput US, Genc Y, Saracoglu I. Cytotoxic and antioxidative activities of Plantago lagopus L. and characterization of its bioactive compounds. Food Chem Toxicol 2012;50:1554-9. doi: 10.1016/j.fct.2012.01.019

69. Jiang Y, Kusama K, Satoh K, Takayama E, Watanabe S, Sakagami H. Induction of cytotoxicity by chlorogenic acid in human oral tumor cell lines. Phytomedicine 2000; 7:48391. doi: 10.1016/S0944-7113(00)80034-3

70. Natarajan N, Thamaraseivan R, Lingaiah H, Srinivasan $P$, Periyasamy BM. Effect of flavonone hesperidin on the apoptosis of human mammary carcinoma cell line MCF-7. Biomed Prevent Nutr 2011;1:207-15. doi: 10.1016/j. bionut 2011.07.001

71. Banjerdpongchai R, Wudtiwai B, Khaw-On P, Rachakhom W, Duangnil N, Kongtawelert P. Hesperidin from Citrus seed induces human hepatocellular carcinoma HepG2 cell apoptosis via both mitochondrial and death receptor pathways. Tumour Biol 2016;37:227-37. doi: 10.1007/ s13277-015-3774-7

72. Yamauchi K, Mitsunaga T, Afroze SH, Uddin MN. Structureactivity relationships of methylquercetin on anti-migration 
and anti-proliferation activity in B16 melanoma cells. Anticancer Res 2017;37:1575-9. doi: 10.21873/ anticanres. 11487

73. Sak K, Lust H, Kase M, Jaal J. Cytotoxic action of methylquercetins in human lung adenocarcinoma cells. Oncol Lett 2018;15:1973-8. doi: 10.3892/ol.2017.7466

74. Chantraine J-M, Laurent D, Ballivian C, Saavedra G, Ibanez R, Vilaseca A. Insecticidal activity of essential oils on Aedes aepgyti larvae. Phytother Res 1998;12:350-4. doi: 10.1002/ ( S I C I ) $1099-1573$ (199808) 12:5<350: : A I D PTR311>3.0.CO;2-7
75. Santos SRL, Melo MA, Cardoso AV, Santos RLC, de Sousa DP, Cavalcanti SCH. Structure-activity relationships of larvicidal monoterpenes and derivatives against Aedes aegypti Linn. Chemosphere 2011;84:150-3. doi: 10.1016/j. chemosphere.2011.02.018

76. Silva WJ, Dória GA, Maia RT, Nunes RS, Carvalho GA, Blank AF, Alves PB, Marçal RM, Cavalcanti SCH. Effects of essential oils on Aedes aegypti larvae: alternatives to environmentally safe insecticides. Bioresour Technol 2008;99:3251-5. doi: 10.1016/j.biortech.2007.05.064

\section{Kemijski sastav te antioksidacijski, citotoksični i insekticidni potencijal valerijane Valeriana alliariifolia u Turskoj}

Valerijana (odoljen) česta je biljna vrsta koja se zbog svojih ljekovitih svojstava od davnina rabi u narodnoj medicini. U ovome se istraživanju utvrdio fitokemijski profil te antioksidacijsko, citotoksično i insekticidno djelovanje tradicionalne vrste koja se za liječenje rabi u Turskoj - Valeriana alliariifolia Adams. Za analizu je maceracijom pripremljeno šest ekstrakata njezina korijena pomoću heksana (HM1), kloroforma (CM1), etanola (EM1, EM2) i vode (WM1, WM2). Jedan je uzorak pripremljen infuzijom vodom (WI) prema tradicionalnom turskom receptu za ljekovite pripravke. Testovima antioksidacijskoga djelovanja pomoću 2,2-difenil-1-pikrilhidrazila (DPPH) i 2,2'-azino-bis(3-etilbenzotiazolin-6sulfonične kiseline (ABTS) izdvojeni su sljedeći ekstrakti s najjačim antioksidacijskim djelovanjem: EM1 (IC ${ }_{50}-\mathrm{DPPH}$ 17,694 $\mu \mathrm{g} / \mathrm{mL}$; ABTS: 23,8 $\mu \mathrm{g} / \mathrm{mL}$ ) i EM2 (IC - DPPH: $20 \mu \mathrm{g} / \mathrm{mL}$; ABTS: 21,5 $\mu \mathrm{g} / \mathrm{mL}$ ). Ekstrakt s heksanom, HM1, iskazao je najveću citotoksičnost $\left(\mathrm{IC}_{50}<10 \mu \mathrm{g} / \mathrm{mL}\right.$ protiv tumorskih stanica HepG2 i HUVEC), a EM2 snažnu citotoksičnost $\left(\mathrm{IC}_{50}<10 \mu \mathrm{g} / \mathrm{mL}\right.$ protiv HepG2 stanica te $\mathrm{IC}_{50} 11,96 \mu \mathrm{g} / \mathrm{mL}$ protiv HUVEC stanica). Ekstrakte s najsnažnijim citotoksičnim djelovanjem također smo analizirali za insekticidno djelovanje protiv odraslih ženki komarca vrste Aedes aegypti te njihovih ličinki. U skladu sa svojom citotoksičnosti, HM1 se pokazao najdjelotvornijim (smrtnost $90 \pm 10 \%$ ). Zbog snažnog antioksidacijskog, citotoksičnog i insekticidnog djelovanja, napravili smo i fitokemijsku analizu ekstrakata HM1, EM1 i EM2 služeći se metodama GC-MS (za HM1) i LC-MS/MS (za EM1 i EM2). Također smo analizirali sastav esencijalnoga ulja dobivenoga mikrodestilacijom korijena $V$. alliariifolia kako bismo ga usporedili sa sastavom HM1, koji je sadržavao hlapljive sastojke. Fitokemijska je analiza pokazala da je glavni sastojak HM1 izovalerijanska kiselina (16\%), a esencijalnoga ulja 1,8-cineol (2,9\%). Glavni sastojci ekstrakata EM1 i EM2 bili su 5-O-kafeoilkvinska kiselina (klorogena kiselina), verbakozid (akteozid) i 3,5-dikafeoilkvinska kiselina. U svjetlu ovih rezultata i dostupne literature, možemo zaključiti da $V$. alliariifolia ima dobar bioaktivni potencijal, koji se može iskoristiti za različite svrhe poput razvoja novih tvari za liječenje bolesti. Razlika u sadržaju između esencijalnoga ulja i ekstrakta HM1 pokazala se golemom te upućuje na to da su razlike u aktivnosti između uzoraka rezultat sastava, zbog čega primjena/liječenje trebaju uvjetovati koja će se vrsta pripravka odabrati. Dodatna je vrijednost ovoga istraživanja što su se u ekstraktima valerijane prvi put otkrili verbaskozid i metilkvercetin rutinozid. 